\title{
Variation in Material Culture: Adoption of Greek Ceramics in an Indigenous Sicilian Site $\left(8^{\text {th }}\right.$ century BCE)
}

\author{
Anna Raudino
}

La Trobe University

\begin{abstract}
The archaeological study of social boundaries through the examination of the material culture reflects the intent to better understand the interaction established between two different cultures. This paper, as part of my $\mathrm{PhD}$ study, identifies and analyses evidence for cultural transformation in southeastern Sicily when indigenous populations came into contact with ancient Greek settlers between the end of the eighth and the beginning of the seventh centuries BCE. In particular, this current study examines indigenous pottery production and distribution, focussing on material from Monte Finocchito in southeastern Sicily and combining archaeological and anthropological approaches with the first archaeometric analyses ever carried out on this artefact assemblage. The study argues on the basis of analysis of pottery fabrics and techniques, as well as shapes and decoration, that indigenous populations maintained robust independent cultures in the early phase of their interaction with the Greeks.
\end{abstract}

Keywords: Mediterranean Archaeology, Archaeometry, Cultural Contacts, Interaction, Immigration, Iron Age, Indigenous Pottery Production, Sicily.

\section{Introduction}

The study of mobility, as a social phenomenon, explores the movement of people in different territories and everything related to it, such as customs, habits, language, ideas and goods. There are different reasons behind mobility and migratory flows, often including social tensions resulting from a range of factors such as war or resource supply and other environmental factors. The whole human history is characterised by a continuous movement of people, within which causes and effects are always different depending on the surrounding environment, the historical period and the dynamic cultural interactions established (Van Dommelen 2012: 403-404; Van Dommelen 2014: 480). The movement of a group toward a foreign land and the inevitable social and cultural interaction with the indigenes could lead to substantial changes in customs and traditions. Usually, all parties involved experience, on different levels, a process of cultural transformation. This process of culture change is never immediate and it faces multifaceted complexities in part determined by social structures and strong identities. Anthropological studies focusing on social and culture interactions, especially in a colonial situation, view that those groups, which recognised themselves as a community even despite their cultural diversity, are more likely to became a community having a new common identity (Said 1978; White 1991; Gandhi 1998; Malkin 2004; Dietler 2010: 13; Van Dommelen 2012: 403). 
Generally, all parties involved experience a process of cultural transformation in favour of the formation of a new common identity, where those groups recognise themselves as a community even despite their cultural diversity (Malkin 1998). Usually, in such contexts, two different groups encounter one another, creating through agreements and exchange a new reality, described as common or contact zones (Pratt 1992; Ferguson \& Whitehead 1992). The place where both groups start a dialogue was described by Richard White as the 'Middle Ground' (White 1991). In accordance with White's theory, Malkin also provides a detailed description of such phenomenon:

Middle Ground is an area in which both play roles according to what each side perceives to be the other's perception of itself. In time this role-playing, the result of kind of double mirror reflection, creates a civilisation that is neither purely native nor entirely colonial-imported. According to changing circumstances each side will also come to emphasize certain aspects of the image constructed of the other, either for the sake of meditation and coexistence or as justification of hostilities (Malkin 1998:133).

In Classical and Mediterranean archaeology movement of people has been put in relation with colonisation, a term used to describe mobility of people involved in a process of expansion and conquest (Lyons \& Papadopoulos 2002: 1-23; Dietler 2010: 17; Sommer 2011: 183; Van Dommelen 2014: 479). This historical process, which usually refers to unequal relationships, often characterises indigenes as groups without strong social structures, while the colonisers are often described as superior (Park \& Burgess 1921: 735; Hodos 2000: 43-44; Leighton 2000: 19). In particular, the terms 'colony' or 'colonisation' have been applied to the study of the ancient Mediterranean with regard to Greek overseas expansion in the south of Italy and Sicily from the end of the eighth century BCE (MacIver 1931; Dunbabin 1948).

Modern studies of archaeology of colonialism (Boardman 1980: 160-189; Bouloumiè 1981; Dietler 1990; 2005) recognise that the model describing a movement of people expanding their power through the occupation of new territories and the domination of a group of people from another culture (Sommer 2011: 189-190; Van Dommelen 2012: 397) is a model related to the colonial empires of the nineteenth century and it does not describe the events in the ancient Mediterranean, especially in the Early Iron Age (Donnellan \& Nizzo 2016: 9-18). Therefore, terms referring to colonial situations are used in this study on the basis that their modern connotations and concomitant modern political significance are not applicable to the ancient Greek world (Van Dommelen 2017: 306).

Sicily, because of its central position in the Mediterranean Sea has been a place where there was mobility of goods and people. In south-eastern Sicily, as well as other territories in the Mediterranean, encounters with Greeks were well underway by the end of the eighth century BCE. During this phase, the indigenous populations occupying the south-eastern coastline of Sicily underwent a significant cultural transformation as the result of a more permanent presence of Greeks in Sicily. During the Iron Age, the Greeks intensified their overseas travel and founded permanent settlement $(\alpha \pi 01 \kappa i \alpha)$. With regard to the studies of ancient Mediterranean archaeology, scholars used to define the interaction between indigenes of Sicily and Greeks through a Helleno-centric point of view, describing these early encounters (also known as precolonisation) as preparatory to the proper colonisation (see for example Dunbabin 1948). 
However, it has been argued that the presence of Greeks in Sicily, at the end of the eighth century, cannot really be described as a phenomenon related to a colonial situation: as Malkin observes, in this early period, it is more likely that disorganised small groups, if not single individuals, migrated to the Western Mediterranean over long periods establishing small Greek outposts with a probable commercial purpose (Sommer 2011: 183-193; Malkin 2016: 289).

This paper focuses on studies of early encounters in a colonial context in the ancient Mediterranean. It examines changes in material culture within the indigenous site of Monte Finocchito, a site located on the top of a moderate hill in south-eastern Sicily, to better understand the relation indigenes engaged with Greeks and in particular with those from Heloros, a Greek outpost settled along the coastline at the end of the eighth century BCE (Fig. 1). Ceramic evidence from Monte Finocchito is examined here in the light of shifts in interpretation of the nature and experience of culture contact. The current study relies on recent archaeometric analyses of ceramics from Monte Finocchito and Heloros (Raudino et al. 2017). Thus, the study of ancient ceramics takes account of many factors and subjects involved in their composition. It is argued that the process of making ceramics and its variability in technology is the consequence of social and cultural interaction between different groups (Arnold 1985; 1999; Costin 2000; Martineau 2001; Santacreu 2014: 133). Drawing on anthropological studies in colonial context (Van Dommelen 1998; 2006; Leighton 2000; Antonaccio 2003; Hodos 2006; Dietler 2010) and the results of archaeometric analyses, this paper will show one of the possible scenarios of the earlier contacts between indigenes and Greeks at the end of the eighth century BCE.
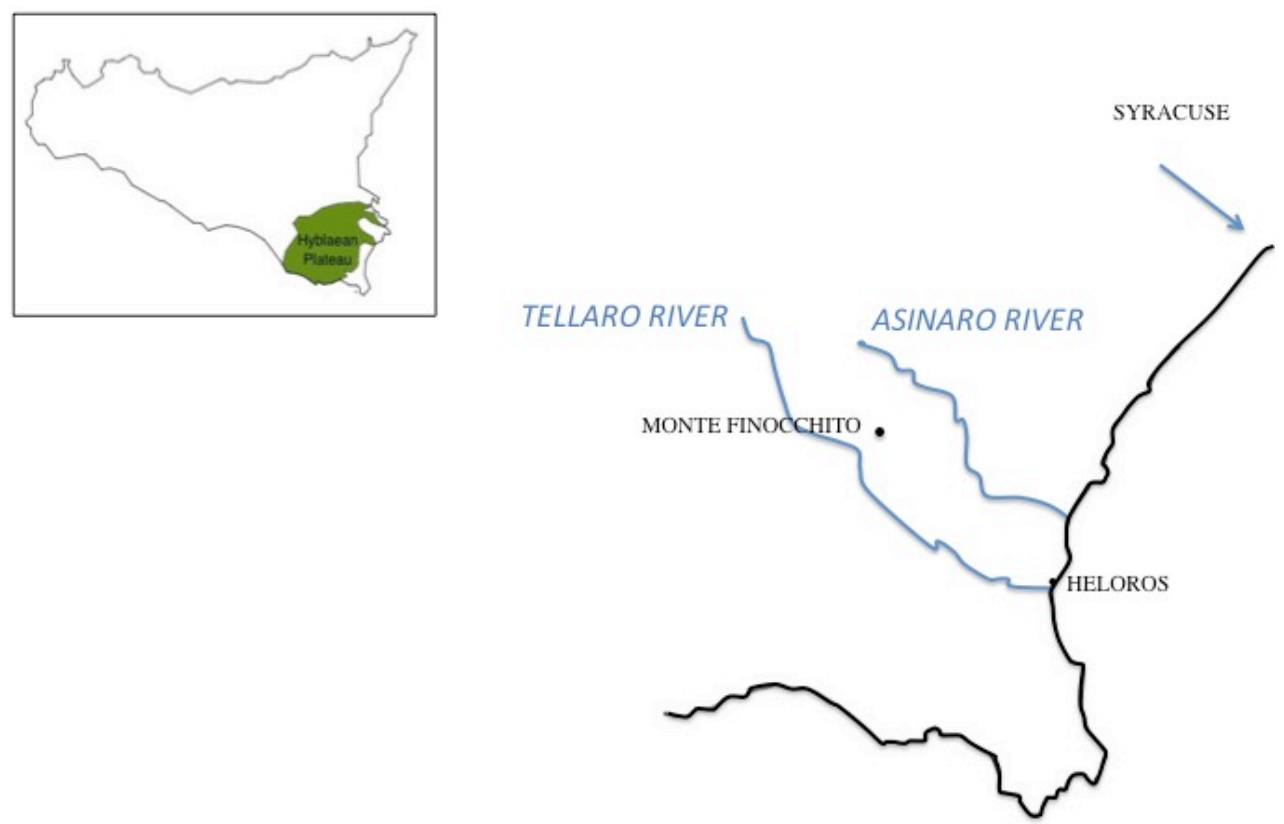

Figure 1. Monte Finocchito, a site located on the top of a moderate hill in south-eastern Sicily, and Heloros a Greek outpost settled along the coastline at the end of the eighth century BCE. 


\section{Material culture in an archaeological context}

With the whole of human history characterised by constant movement, change in artefacts types and styles has become one of the main evidence that archaeology has to detect social interaction (Van Dommelen 2012). Archaeological research therefore sees material culture as a way to read the alterations of traditional customs. In this regard, one of the ways to identify the development and trajectory of social change and shifting cultural boundaries is the study of the production and distribution of ceramic materials. Dietler observes how the acquisition of new different objects has to be studied considering that "foreign objects are of interest not for what they represent in the society of origin but for their perceived use and meaning in the context of consumption" (Dietler 2010: 68). Already in the late 80s, Sackett $(1982 ; 1990)$ suggested that to explain the creation or change of a specific style in material culture, the study has to contemplate the existence of a relation amongst different groups and even sub-groups in contact with an external group, with different identities along the cultural boundaries. Usually, interactions amongst individuals and groups, which bear their different cultures, occurred in trading or colonial contexts and the effect, as archaeological studies of colonial context suggest, is always different (Dietler 2010).

The most recent studies on colonialism claim that intercultural consumption is the main process by which to understand the practice related to the initial contact in a colonial context (Dietler 2010). Methodologically, the study of consumption in a context of ancient colonialism requires a more careful examination of what was adopted and how, which goods and why only some of them were adopted. Dietler observes how the acquisition of new different objects has to be studied through a different perspective considering that "foreign objects are of interest not for what they represent in the society of origin but for their perceived use and meaning in the context of consumption" (Dietler 2010: 68). Thus, observing the ancient colonial environments we usually find that not all of the Greek products were introduced to the local culture, but only a few selected types.

From an archaeological point of view, consumption describes how objects or goods, introduced as a consequence of a cultural contact, were utilised in a new social context. In the last two decades and more, the study of consumption in archaeological contexts, especially through anthropological, and also social science studies has increased (Baudrillard 1998; Bourdieu 1984; Dietler 2010; Douglas \& Isherwood 1979; Miller 1987, 1995). Recent archaeological studies claim that it is through its consumption that the culture is constructed and it passes through different ways of interaction (Comaroff \& Comaroff 1997; Douglas \& Isherwood 1979; Dietler 1990; Vander Linden 2001; Van Dommelen 2006; Santacreu 2014).

\section{Case of study}

This study focuses on Monte Finocchito, a crucial indigenous site for understanding the process of cultural transformation in Sicily during the eighth century BCE. The site lies on the Hyblaean Plateau overlooking the Tellaro River (Fig. 1). Monte Finocchito, and in particular its necropolis, was excavated by Paolo Orsi in 1892 (Orsi 1894: 157; 1896: 242), and later on an investigation was undertaken in the twentieth century (Frasca 1977: 116-118; 1981). During the explorations and through further studies (Steures 1980: 91-92; 1998) more than 500 tombs were counted. 
The necropolis, which has features common to other nearby necropolis (Orsi 1899: 68-71; Leighton 2015: 191), is characterised by rock-cut tombs with a rectangular and often semielliptical chamber preceded by a short dromos. Usually, the entrance was closed by a stone doorslab locked with a wooden bar. In proximity to the entrance was a low ledge on which the head of the dead was laid. Normally, the dead were wearing ornaments for clothing, such as bronze and iron fibulae, rings (rectangular or convex), bronze foils and little chains. Vessels were placed close to the feet, around the body or deposited in corners of the tomb. The set of ceramics, which recurs almost constantly in the explored tombs, was characterised by the presence of a large bowl surrounded by smaller bowls, sometimes small plates and cups, and drinking vessels, such as trefoil oinochoai and cups.

Chronologically, Orsi recognised the Finocchito culture as one of the most representative of the third Sicul period where Greek ceramics appeared in a large quantities in funeral contexts and were mixed with indigenous ceramics. In the 1980s, Frasca and Steures, independently proposed a general chronology for the tombs based on goods typology. Frasca (1981) proposed three main phases for Monte Finocchito: the first (Phase I) runs from 850/800 to 735/730 BCE; the second phase is sub-divided into two main periods (making three phases overall), Phase IIA (735/730 BCE to 700 BCE) and Phase IIB (700 and 665 BCE). By contrast, Steures (1980; 1988) proposed a different chronology: here, the earliest phase runs from 750 to $730 \mathrm{BCE}$, while a transitional phase is dated between 730 and 715 BCE, with a final period between 715 and 690 BCE. It is during the IIA (Frasca) or transitional phase (Steures) that indigenous ceramics were found in grave assemblages with wares resembling Greek ceramic types, such as kotylai or imitation of Thapsos cups and cups in Protocorinthian-style (Frasca 1981: 66-70).

Archaeological records suggest that a Greek site, known as Heloros, considered Syracuse's first sub-colony, was established at the end of the eighth century BCE along the coastline, overlooking the indigenous site of Finocchito (Voza \& Lanza 1994: 113-120; Copani 2010:1-5). The Greek settlement of Heloros was along the coastline of the Hyblean Plateau, 400 metres north of the Tellaro River and $30 \mathrm{~km}$ from Syracuse (Currò 1965). Ancient sources do not refer to its foundation and they only describe it as a Syracusan phrourion (Aelian, Hist. An., XII, 30).

The first archaeological explorations at the Greek site were organised in 1899 and 1927 by Orsi (Currò 1965); this is when the site's Hellenistic phase was discovered. The site was revisited later on by Militello in 1965 and then by Voza. During the excavation ceramics in Protocorinthianstyle and local imitations of Greek ceramics as well as possible imports, were discovered just below the first phase of the earliest Greek houses of Heloros. Meanwhile, belonging to the first phase of the earliest Greek houses, are imported Greek vessels in Protocorinthian-style and also local imitation of Protocorinthian ceramics, mainly cups, lekythoi and kylikai, dated at the seventh century BCE (Militello 1965: 301-302). Militello dated the fragments recorded below the first phase of the earliest Greek houses to the very end of the eighth and the beginning of the seventh century BCE. He also observed that because they were found below the early Greek houses, the ceramics in Protocorinthian-style were probably related to a previous phase when a group of indigenous people occupied Heloros in a dependent relationship with Syracuse, and in a phase that just preceded the establishment of the Greek settlement (Militello 1965: 301-302; Guido 1967). These Greek ceramics in Protocorinthian-style (probably local imitations) seems to be coeval with some of the ceramic types in Protocorinthian-style from Monte Finocchito 
(Voza 1968-69: 360-362; 1973a: 189-192; 1973b: 117-126; 1980; 1980-81: 685-688; 1989: 159_ 163; Voza \& Lanza 1994).

On the basis of the presence of such early ceramics in Protocorinthian-style at Heloros and the occurence of similar Greek ceramic types at Finocchito, several theories regarding the role Heloros had at the end of the eighth century BCE and consequentially, its relationship with Finocchito have been formulated. La Torre proposes that Heloros, due to its position, engaged in commercial relationships with indigenes (La Torre 2011: 73), while Massimo Frasca has proposed that Heloros was probably a trade centre where merchants from Syracuse and other Sicilian harbours commercialised and exchanged their goods, which then spread around the indigenous necropolis of Finocchito (Frasca 2016: 76). However, I will argue that the relationship Greeks and locals engaged at the end of the eighth century BCE might not have been of a primarily commercial nature due to the absence of Greek imports at Monte Finocchito.

\section{Ceramic study}

At the end of the eighth century BCE, the indigenes from Monte Finocchito adopted new vessel types associated with Greek ceramic types that were incorporated and diffused around this site, and in particular within the set of ceramics characterising the funeral rituals. It is possible that Greek ceramics were also employed in other contexts, religious or domestic, but the archaeological records are limited to the excavated necropolis. The repertoire of Greek ceramics that indigenes of Monte Finocchito adopted in the mortuary sphere was confined to drinking cups: Thapsos cups type, kotylai, kyathoi, skyphoi, and oinochoai and cups in Protocorinthianstyle (Fig. 2).

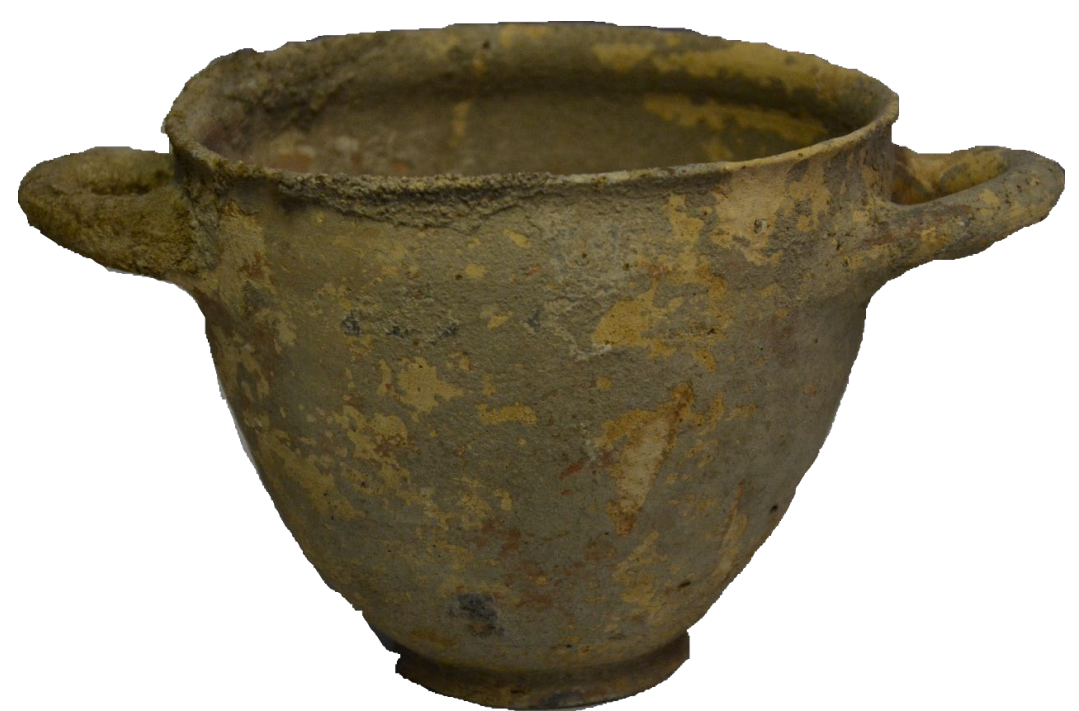

Figure 2. Kotyle in Protocorinthian-style from Monte Finocchito (end 8th century BCE)

With regards to Monte Finocchito, a general distinction between imported material and imitations of Greek types locally manufactured was initially put forward by Paolo Orsi (1894; 1896). He distinguished, as imitations of Greek Geometric pottery, a group of trilobate oinochoai which he claimed were manufactured by Greeks living along the Sicilian coast in a period that preceeded the establishment of the Greek settlers, while a second class, corresponding to 
oinochoai in Protocorinthian-style, was manufactured in Sicily by Greek ceramists during the eighth and the seventh century, when the first colonies were settled (Orsi 1894: 58). Subsequently, Frasca and Steures in their respective studies, noted that imports as well as ceramics imitating Greek types were common. In particular, Frasca claims that the majority of the ceramics imitate Greek pottery in Protocorinthian-style, in particular the oinochoai. Meanwhile, he classifies as possible imports a small group of cups in Protocorinthian-style (Frasca 1981: 15-17). On the other hand, Steures (1988: 74-80) classified as imports 'Thapsos' cups that she classified as P22 type (Steures 1988: table 5.7) and the kotylai in Protocorinthianstyle (P21 type).

\section{Methods and results}

Even if we take it as an unequivocal fact that during the eighth century the indigenous ceramics of Monte Finocchito were influenced by Greek ceramic models, this development surely represents a period of transition and social/cultural encounters that may not necessarily represent a cultural change or a change of social identities (Van Dommelen \& Knapp 2010). As part of this investigation into possible connections in pottery manufacture and to what degree Greek models influenced indigenous production at Monte Finocchito, archaeometric analyses were undertaken. Around 300 ceramic samples, both from Monte Finocchito and Heloros, were examined utilizing portable XRF spectrometry (pXRF).

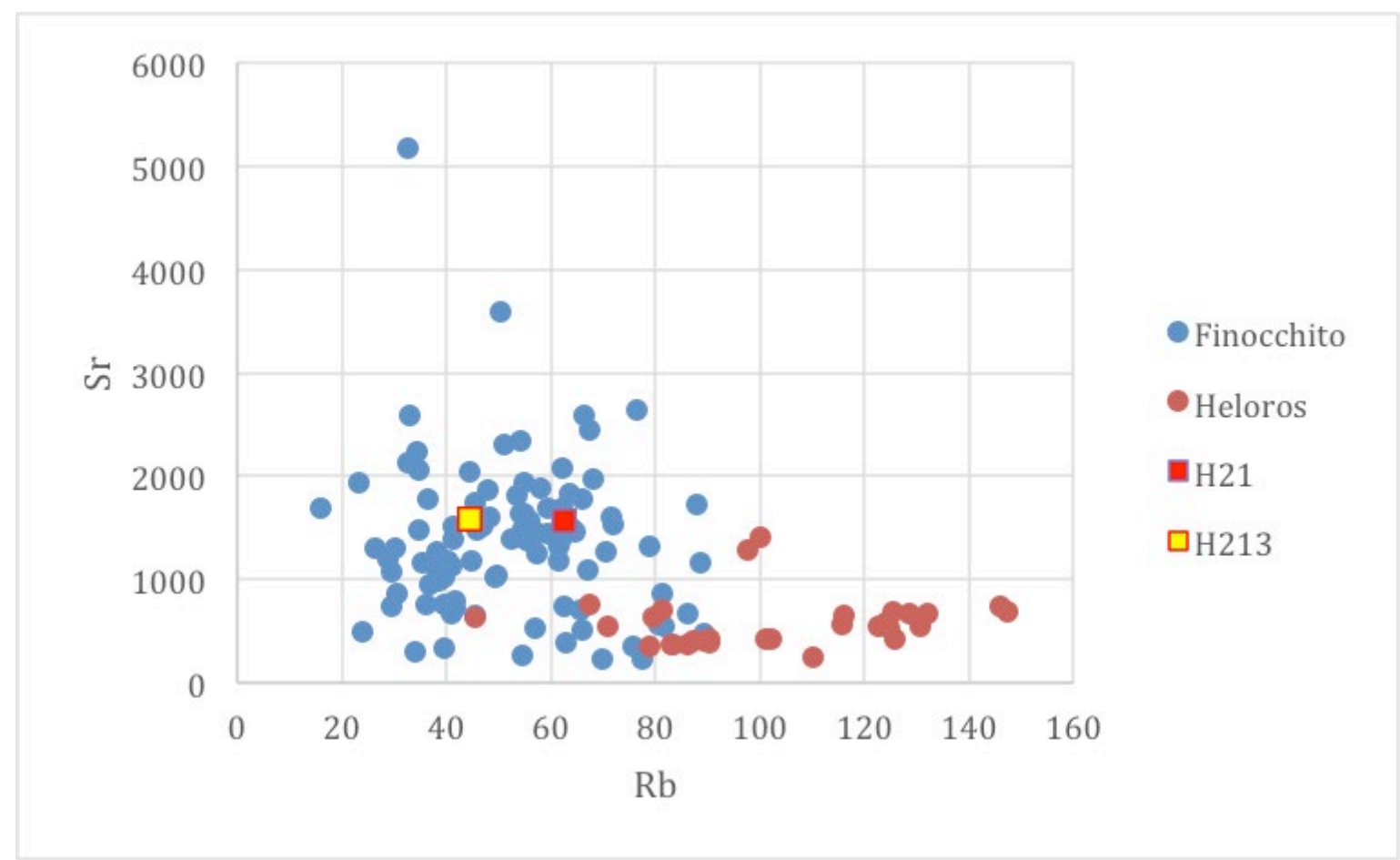

Figure 3. Scatterplot A with the combination of rubidium $(\mathrm{Rb})$ and strontium $(\mathrm{Sr})$ showing the ceramic samples analysed with Bruker III-SD

The archaeometric analyses were carried out at the Paolo Orsi museum, in collaboration with Prof. Robert Tykot (University of South Florida) (Raudino et al. 2017). The instrument used was a hand-held Bruker III-SD. Monte Finocchito ceramics selected up until this point allow data to 
be gathered from across the whole period that runs from the end of the eighth to the seventh century BCE. Accordingly, ceramics from Heloros were also tested to investigate any possible correspondence between the ceramics discovered at both sites. The samples available in the museum were restricted to a small quantity, and the samples selected include: Thapsos cups type, closed vessels, kotylai and cups (Voza 1968-1969: 360-362; Voza 1973a, 117-126; Voza 1973b: 134-135; Voza \& Lanza 1994: 462-463).

The outcome from the archaeometric analyses (scatterplot A) suggests that Monte Finocchito samples (blue dots) are clustered within one main group, while Heloros (red dots) ceramics partially differ from the Monte Finocchito group (Fig. 3). The statistical analysis shows that amongst the Heloros ceramics, two ceramic vessels in Protocorinthian-style, here named H21 and H213 (Fig. 4), fall within the Monte Finocchito clustered group (Raudino et al. 2017).
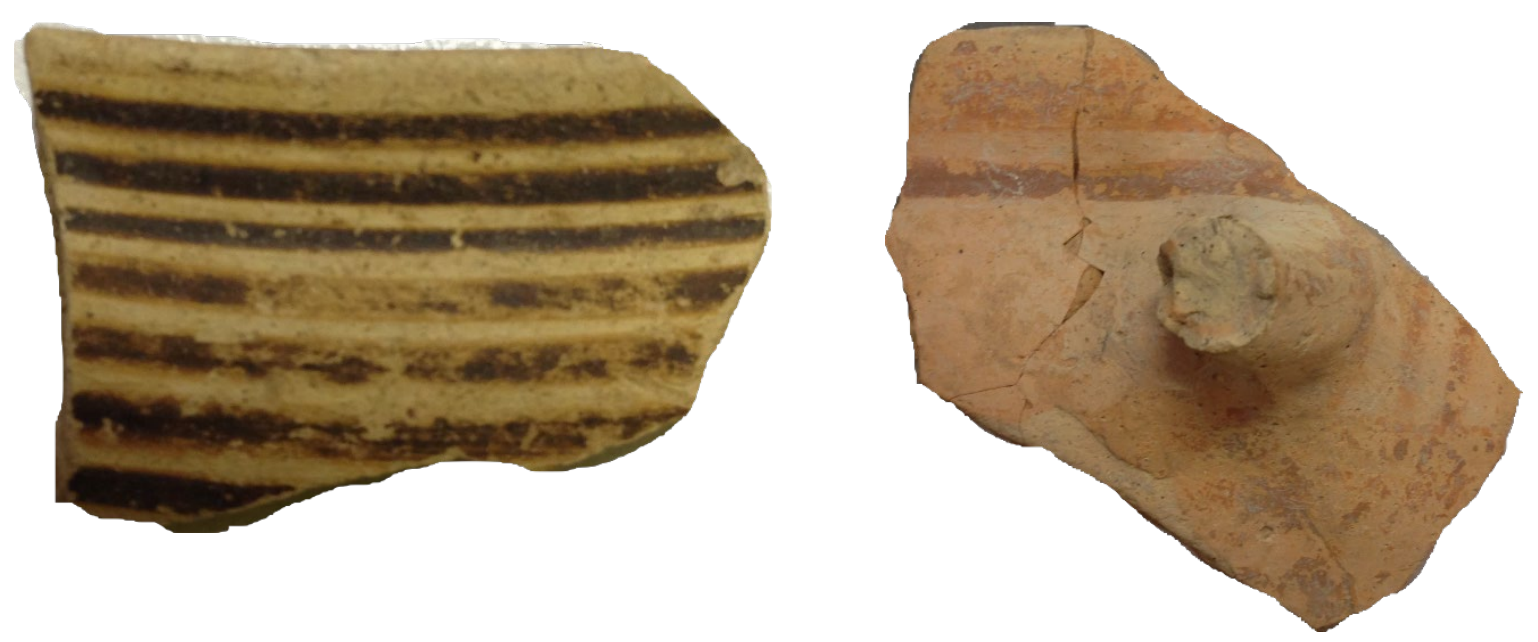

Figure 4. On the left hand side ceramic sample H21 in Protocorinthian style from Heloros; on the right hand side, ceramic sample H213 (Protocorinthian style cup)

This suggests that the clay used for Finocchito potsherds was the same for the whole period, from the end of the eighth to the beginning of the seventh century BCE. The scatterplot also shows that just a low number of non-local ceramics, which resemble Greek types in shape, occur (Raudino et al. 2017). With regard to Heloros, the scatterplot B (Fig. 5) of the Heloros ceramics shows three main groups: Group A (green circle), Group B (red circle), and Group C (blue circle). Group A (green circle) is mainly characterised by Protocorinthian-style cups. Group A includes samples H21 and H213, which in scatterplot A showed a similar trace element signature to that of the potsherds of Monte Finocchito. Therefore, it is possible that ceramic samples H21 and H213, due to their similarity with Monte Finocchito ceramics in Protocorinthian-style and because clustered within the same group (see scatterplot A), correspond to the most ancient ceramics from Heloros discovered under the earliest Greek habitations and therefore dated at the end of the eighth BCE (Militello 1965: 302). If so, the final outcome suggests that Heloros Group A may correspond to the early ceramic fragments from Heloros locally manufactured and coeval with the Protocorinthian-style ceramics from Finocchito. These data may further confirm that a group of indigenous people in relation with Greeks or Greeks occupied Heloros at the end of the eighth century, and manufactured those ceramics clustered within Heloros 
Group A using the same clay source indigenes used at Finocchito. With regard to the ceramics from Groups B and C, they are all ceramics dated to the seventh century (Militello 1965). The archaeometric analysis suggests that the seventh century pottery from Heloros is quite different from the earliest group A, indicative of new and different producers and also production methods, during the seventh century.

In addition, petrographic analysis (currently under review for publication) on a smaller group of ceramics from Monte Finocchito further confirms that even those ceramic types inspired by Greek models were locally produced, identifying local fabrics.

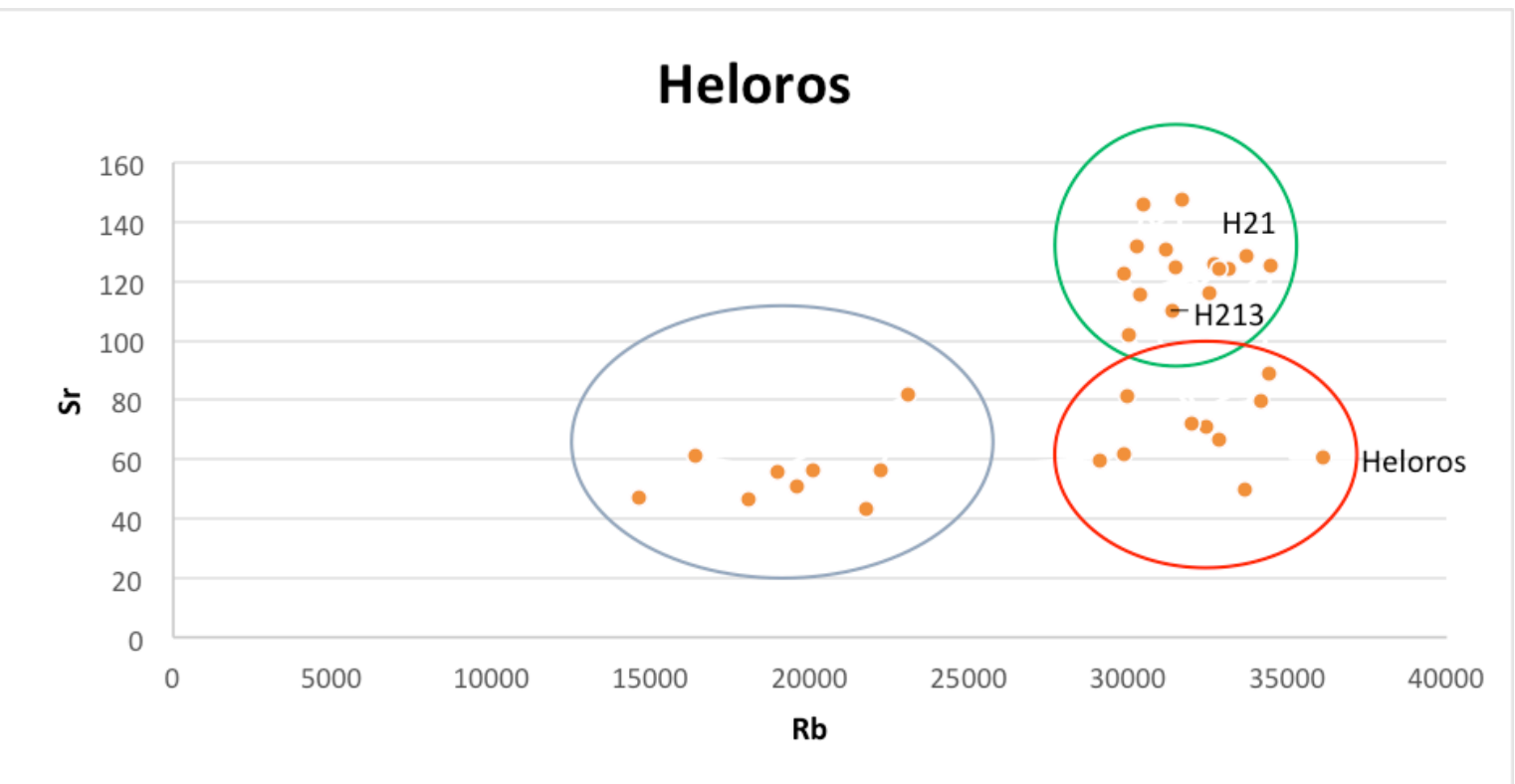

Figure 5. Scatterplot B with the combination of strontium ( $\mathrm{Sr}$ ) and robium (Rb) shows Heloros ceramics clustered in three main groups. Group A (green circle), Group B (red circle) and Group C (blue circle).

\section{Discussion}

At the end of the eighth century BCE a process of cultural transformation began in Sicily and it involved the indigenous site of Monte Finocchito (Frasca 1981; Steures 1988). Change in artefacts has been documented at Finocchito and it is the reflection of a migration of Greeks towards Sicily. The preliminary overall outcome of this research showed that from the end of the eighth century BCE Greek ceramic types were present in Monte Finocchito. Only a specific repertoire of Greek ceramics was adopted and it was confined to drinking containers. This new repertoire was always associated with ceramics locally produced and it was complementary to vessels of indigenous production. Drinking vessels, jugs and trefoil oinochoai were also a common repertoire occurring in the indigenous funeral sphere. This might suggest that the Greek ceramic types were adopted within a context that might have already incorporated similar ceremonies characterised by the consumption of food or beverages in general or that possible containers of food were offered to the dead.

Moreover, the outcome from the archaeometric analysis suggests that there were no samples of original Greek vessels and that the Greek ceramic types circulating were locally made. Therefore, 
at Monte Finocchito there were not samples of original Greek vessels to imitate. Equally, local ceramics resembling Greek artistic products are recorded at Monte Finocchito, indicating that an interaction between these groups certainly occurred. Hence, I argue that it might be possible that a small group of Greeks occupied Heloros at the end of the eighth century BCE interacting with those from Monte Finocchito.

With regard to the type of relationship indigenes and Greeks engaged, it seems that the absence of actual Greek imports at Monte Finocchito and the presence of only a small group of nonlocal ceramics are not, at least at this early stage, significant enough to justify substantial commercial relationships between these groups (La Torre 2011: 73; Frasca 2016: 76). Therefore, while the relationship between the indigenous people and the Greeks may not have been of a primarily commercial nature, it might be possible that these early contacts incorporated the exchange of skilled labour (Papadopoulos 1994: 450-461; Raudino et al. 2017).

The observation of the change in material culture within Monte Finocchito and the results given by the archaeometric analyses indicate that indigenes and Greeks interacted by sharing knowledge, as they used the same source of clay, shared the resources and presumably they created a system for communicating. Thus, it might be possible that it is through the exchange of knowledge, rather than the simple trade of an object, that the integration process began. Meanwhile, the adoption of new types of drinking containers, particularly important in Greek culture and to which the indigenous community of Monte Finocchito could relate, may reflect the cultural practices that may have become fundamental communication channels between the two groups.

\section{Acknowledgments}

I am indebted to the many people who have provided me with assistance and encouragement, both professionally and personally, through the duration of this research project. I acknowledge and thank my supervisors Dr. Gillian Shepherd, Professor Christopher Mackie and Professor John Webb. In particular, I would like to thank John who has guided me through the field of the archaeometric studies. Moreover, I thank Professor Robert Tykot and Dr Andrea Vianello with whom I collaborated in the initial archaeometric analyses at the Paolo Orsi museum. My sincere thanks to Professor Davide Tanasi who introduced me to the field of archaeometry and for his precious advices. I am also extremely grateful to the Paolo Orsi museum that generously provided access to the archaeological material from Monte Finocchito and Heloros. In particular, I thank the director of the museum Dr. Gioconda Lamagna and her successor Dr. Concetta Ciurcina, Dr. Giuseppina Monterosso and Dr. Angela Maria Manenti. Finally, warm thanks go to the editors of this journal, and in particular M. Revello Lami for her observations and comments. 


\section{References}

Antonaccio G., 2003. Hybridity and the cultures within Greek culture, in: C. DOUGHERTY \& L. Kurke (eds.), The Cultures Within Ancient Greek Culture: contact, conflict, collaboration. Cambridge: Cambridge University Press, 57-74.

ARNOLD, D., 1985. Ceramics theory and cultural process. New York: Cambridge University Press.

ARNOLD, D., 1999. Does the standardization of ceramic pastes really mean standardization? Journal of Archaeological Method and Theory 7: 333-375.

BAudriLLARD, J., 1998. The Consumer Society: Myths and Structures. Nottingham: Nottingham Trent University.

BoARDman, J., 1980. The Greeks Overseas: Their early colonies and trade. New York: Thames and Hudson (1st ed.).

Bouloumié, B., 1981. Le vin étrusque et la première hellénisation du Midi de la Gaule. Revue Archéologique de l'Est 32: 75-81.

Bourdieu, P., 1984. Distinction: A Social Critique of the Judgement of Taste. Cambridge: Harvard University Press.

Comaroff J. L., \& J. Comaroff, 1997. OfReveletation and Revolution (vol. 2). The Dialects of Modernity on a South African Frontier. Chicago: The University of Chicago Press.

Copani, F., 2010. Greci ed indigeni ad Eloro. Grecs et indigènes de la Catalogne à la Mer noire: actes des rencontres du programme européen Ramses 2: 1-5.

Costin, C., 2000. The use of Ethnoarchaeology for the Archaeological Study of Ceramic Production. Journal of Archaeological Method and Theory 7(4): 377-403.

Currò, M. T. 1965. P. Orsi, Eloro. I. Campagna di scavo del 1899. Monumenti Antichi 47: 206287.

DieTLer, M., 1990. Exchange, Consumption and colonial Interaction in the Rhòne Basin of France: A study of Early Iron Age Political Economy. Ph.D Dissertation, University of California, Berkeley.

DieTLER, M., 2005. The archaeology of colonization and the colonization of archaeology: Theoretical challenges from an ancient Mediterranean colonial encounter. The Archaeology of Colonial Encounters: Comparative Perspectives: 33-68.

DieTLer, M., 2010. Archaeologies of Colonialism: Consumption, Entanglement, and Violence in Ancient Mediterranean France. Berkeley: University of California Press.

Donnellan, L., \& V. Nizzo, 2016. Conceptualising early Greek colonisation. Introduction to the volume, in: L. DonnelLan \& V. Nizzo (eds.), Conceptualising early Colonisation. Roma: Istituto Storico Belga di Roma.

Douglas, M., \& B. IsHerwood, 1979. The world of Goods: Towards an Anthropology of Consumption. London: Allen Lane.

Dunbabin, T. J., 1948. The Western Greeks. Oxford: Oxford University Press.

Ferguson, R. B., \& D. Whitehead, 1992. The violent edge of empire, in R. B. Ferguson \& D. WhiteHEAd (EDS.), War in the Tribal Zone: Expanding States and Warfare. Santa Fe: School of American Research Press, 1-10.

FrasCA, M., 1977. Intervento al Convegno su Insediamenti coloniali in Sicilia nell'VIII e VII secolo a.C. Cronache di Archeologia 17: 116-118.

FrasCA, M., 1981. La necropoli di Monte Finocchito. Cronache di Archeologia 20: 13-103

FrASCA, M., 2016. Archeologia degli Iblei. Indigeni e Greci nell'altopiano ibleo tra la prima età e la seconda età del Ferro. Ragusa: Edizioni Storia e Studi Sociali.

GANDHI, L., 1998. Postcolonial Theory: a critical introduction. New York: Colombia University Press. 
Guido, M., 1967. Sicily: an archaeological guide, London: Faber and Faber.

Hodos, T., isteper2000. Wine wares in protohistoric eastern Sicily. Ancient Sicily: Archaeology and History from Aeneas to Augustus: 41-54.

Hodos, T., 2006. Local Responses to Colonization in the Iron Age Mediterranean. London: Routledge.

La Torre, G., 2011. Sicilia e Magna Grecia. Archeologia della colonizzazione greca d'Occidente, Bari: Laterza.

Leighton, R., 2000. Time versus Tradition: Iron Age Chronologies in Sicily and Southern Italy. London: Accordia Research Centre (University of London).

LEIGHTON, R., 2015. Rock-cut tombs and funerary landscapes of the Late Bronze and Iron Ages in Sicily: New fieldwork at Pantalica. Journal of Field Archaeology 40(2): 190-203.

LyOns, C. L., \& J. K. PApadopoulos, 2002. The Archaeology of Colonialism: Issues and Debates. Los Angeles: The Getty Research Institute.

MacIVer, D. R., 1931. Greek Cities in Italy and Sicily. Oxford: Clarendon Press.

MALKIN. I., 1998. The Returns of Odysseus: Colonization and Ethnicity. Los Angeles: University of California Press.

Malkin, I., 2004. Postcolonial concepts and ancient Greek colonization. Modern Language Quarterly 65(3): 341-364.

Malkin, I., 2016. Migration and Colonization. Turbulence, Continuity, and the Practice of Mediterranean Space $\left(11^{\text {th }}-5^{\text {th }}\right.$ centuries BCE), in: M. DABAG, D. HALLER, N. JASPERT \& A. Lichtenberger (eds.), New Horizons: Mediterranean Research in the 21st Century. Pederborn, Ferdinand Schöningh: 285-307.

MARTINEAU, R., 2001. Methodology for the archaeological and experimental study of pottery forming techniques, in S. Di PIETRO (ed.), Ceramics in the Society: Proceedings of the 6th European Meeting of Ancient Ceramics. Fribourg: University of Fribourg (Department of Geosciences, Mineralogy and Petrography), 209-215.

Militello, E., 1965. Eloro. III. Relazione degli scavi del 1958-59. Monumenti Antichi 47: 299335.

Miller, D., 1987. Material culture and Mass Consumption. Oxford: Blackwell.

Miller, D., 1995. Acknowledging Consumption: A Review of New Studies, London: Routledge.

Orsi, P., 1894. La necropoli sicula del terzo periodo al Finocchito presso Noto (Siracusa). Bullettino di Paletnologia Italiano 20: 23-26; 37-94.

Orsi, P., 1896. Noto. Necropoli sicula del Monte Finocchito. Notizie degli Scavi: 242-243.

Orsi, P., 1899. Eloro. Ubicazione di questa antica città sulla sinistra del Tellaro nel comune di Noto. Notizie degli scavi di Antichità: 241-244.

Papadopoulos, J. K., 1994. Early Iron Age Potter's Marks in the Aegean. Hesperia 63(4): 437507.

PARK, R. E., \& E. W. BurgesS, 1921. Introduction to the Science of Sociology. Illinois: The University of Chicago Press.

PRATT, M. L., 1992. Imperial Eyes: Travel Writing and Transculturation. London: Routledge.

Raudino, A., R. Tykot, \& A. Vianello, 2017. Monte Finocchito and Heloros Pottery Production: New evidence through technological studies and material analysis. Open Archaeology, 3: $247-254$.

SACKETT, J. R., 1982. Approaches to style in lithic archaeology. Journal of Anthropological Archaeology 1: 59-112.

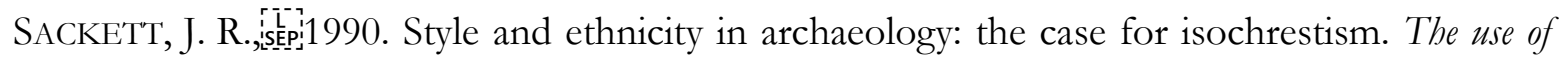


Style in Archaeology: 32-43.

SAID, E. W., 1978. Orientalism. New York: Pantheon Books.

SANTACREU, D. A., 2014. Materiality, Techniques and Society pottery production. The technological study of archaeological ceramics through paste analysis. Warsaw: De Gruyter Open.

Sommer, M., 2011. Colonies-Colonisation-Colonalism: A Typical Reappraisal. Ancient West \& East 10: 183-193.

Steures, D.C., 1980. Monte Finocchito Revisited. Part 1: The Evidence 2. Amsterdam: Allard Pierson Series, 91-92.

Steures, D. M., 1988. Monte Finocchito revisited. Part 2, Seriation and Demography, Amsterdam: Allard Pierson Series.

VAnder Linden, M., 2001. Social Dynamics and Pottery Distribution in the Faro Department, Northern Cameroon. African Archaeological Review 18(3): 135-151.

Van Dommelen, P., 1998. On colonial Grounds: A comparative Study of Colonialism and Rural Settlement in First Millennium BC West Central Sardinia. (Doctoral thesis). Leiden: Faculty of Archaeology, Rijksuniversiteit of Leiden.

VAN DOMmELEN, P., 2006. The Orientalizing phenomenon: hybridity and material culture in the western Mediterranean, in C. RIVA \& N. C. VELLA (eds.), Debating Orientalization: multidisciplinary approaches to change in the ancient Mediterranean. Sheffield: Equinox, 135-152.

Van Dommelen, P., 2012. Colonialism and Migration in the Ancient Mediterranean. Annual Review of Anthropology 41: 393-409.

Van Dommelen, P., 2014. Moving on: Archaeological Perspectives on Mobility and Migration. World Archaeology 46(4): 477-483.

Van Dommelen, P., 2017. Colonial constructs: Colonialism and archaeology in the Mediterranean. World Archaeology 28(3): 305-323.

VAn Dommelen, P., \& A. B. KNAPP, 2010. Material connections: mobility, materiality and Mediterranean, in P. VAN Dommelen \& A. B. KnAPP (eds.), Material connections in the ancient Mediterranean: mobilit, materiality and Mediterranean identities. London: Routledge, 1-18.

VOZA, G., 1968-1969. L'attività della Soprintendenza alle Antichità della Sicilia Orientale fra il 1965 e il 1968. Kokalos 14-15: 360-362.

Voza, G., 1973a. Eloro, in P. PelagatTi \& G. Voza (eds), Archeologia nella Sicilia Sud-Orientale. Naples: Centre Jean Bérard, 117-126.

VozA, G., 1973b. Eloro in età protoarcaica, in P. PelagatTi \& G. VOZA (eds), Archeologia nella Sicilia Sud-Orientale. Naples: Centre Jean Bérard, 134-135.

VozA. G., 1980. 'Eloro', in E. GABBA \& G. VAllet (eds), La Sicilia Antica I.3. Città greche e indigene di Sicilia: documenti e storia. Naples: Storia di Napoli e della Sicilia, Società editrice, 544-553.

VOZA, G., 1980-1981. L'attività della Soprintendenza alle Antichità della Sicilia Orientale. Kokalos: 26-27 (2, 1): 685-688.

VOZA, G., 1989. Eloro. Storia della ricerca archeologica. Bigliografia topografica della colonizzazione greca in Italia e nelle isole tirreniche 7: 159-163.

VOZA, G., \& M. T. LANZA, 1994. Eloro. Enciclopedia dell'Arte Antica Classica e Orientale 2: 462-463. White, R., 1991. The Middle Ground: Indians, empires, and republics in the Great Lakes region, 16501815. Cambridge: Cambridge University Press. 
